\title{
Optimization of $\mathrm{ACH}$ coagulant, settling time and powdered activated carbon as coagulant aid with economic analysis
}

\author{
Omar I.A. ${ }^{1}$ and Aziz S.Q. ${ }^{2 *}$ \\ ${ }^{1}$ General Directorate of Water and Sewerage, Ministry of Municipality and Tourism, Erbil, Kurdistan Region, Iraq \\ 2Department of Civil Engineering, College of Engineering, Salahaddin University-Erbil, Kurdistan Region, Iraq \\ Received: 12/06/2021, Accepted: 10/08/2021, Available online: 05/10/2021 \\ *to whom all correspondence should be addressed: e-mail: shuokr.aziz@su.edu.krd, shoker71@yahoo.com \\ https://doi.org/10.30955/gnj.003797
}

\section{Graphical abstract}

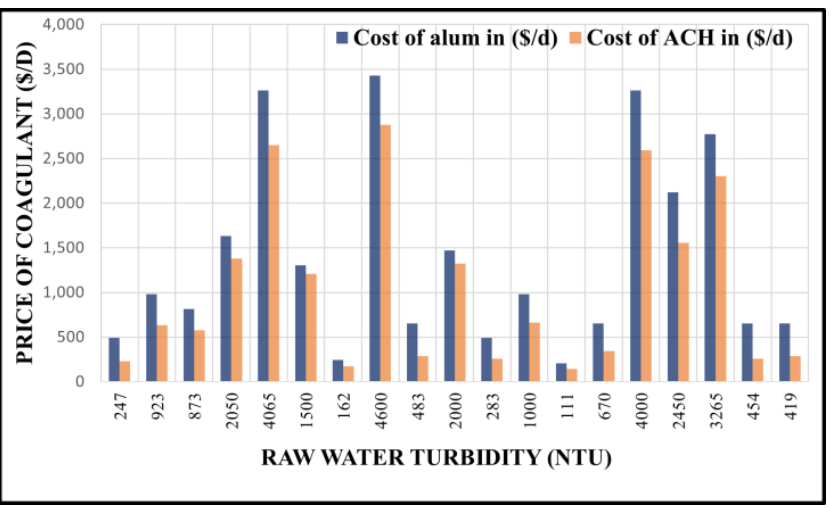

\section{Abstract}

Regular water treatment-plant (WTP) comprises of a number of units. Of course, problems exist throughout design and operation of the WTP units. Consequently, the current research aimed to minimize the shortcomings of the coagulation, sedimentation, and the adsorption methods through applying optimal process for these units. Additionally, economic analysis and the derivation mathematical models for the new coagulant (Aluminum Chlorohydrate $(\mathrm{ACH})$ ) and the traditional aluminum sulphate coagulant (Alum) were another objective of this work. Optimum coagulants for alum and $\mathrm{ACH}$ were obtained and presented for different raw water turbidities. The optimum settling time of 30 minutes and 40 minutes have been found for the settling of 1000 and 2000 NTU raw water samples. Best dosages of 0.1 and $0.25 \mathrm{~g} / \mathrm{L}$ of powdered actived carbon (PAC) were obtained for raw water turbidity of 419 , and 1000 NTU which increased the removal efficiency of $28.95 \%$, and $25.71 \%$, respectively. Furthermore, the economic study for alum and $\mathrm{ACH}$ revealed that using $\mathrm{ACH}$ instead of alum led to reduction of cost by $32 \%$. Commonly, it can be concluded that using $\mathrm{ACH}$ instead of alum is better because it is cheaper and more efficient. The predicted equations for the optimum dosages $(\mathrm{Y})$ for alum $(\mathrm{mg} / \mathrm{L})$ and $\mathrm{ACH}(\mu \mathrm{l} / \mathrm{L})$ dosages $(\mathrm{X})$ were $\mathrm{Y}=$ $0.04 x+14.42$, and $Y=0.01 x+0.72$, respectively.
Keywords: Adsorption, coagulation, Greater-Zab river, optimization, settling, treatment units.

\section{Introduction}

Water treatment plant (WTP) can be described as water processing to attain water quality that meets specific enduser or community objectives or norms through its regulatory organizations (Crittenden et al., 2012). Most present drinking WTPs use conventional treatment methods like intake, coagulation-flocculation, sedimentation, sand filtration, and disinfection to produce fresh potable water (Spellman, 2003, Aziz and Mustafa, 2019). The individual treatment plant units have been intended to take into account the drinking water requirements and to identify areas that need enhancement to improve the functioning of WTP and to achieve better outcomes in terms of water quality, operating costs, water wastage, etc. (Khan and Ahmad, 2018). WTP practice development has a rich background of empirical and science innovations and difficulties that have been addressed and overcome (Crittenden et al., 2012). A WFP's performance assessment is a method for measuring functioning efficiencies based on certain performance indices such as degree of removal of pollutants such as turbidity, color, suspended impurities, etc. (Vieira et al., 2008).

Water treatment or purification is regarded as a critical challenge, particularly in developing countries since this treatment is an important tool for preserving public health and the environment by eliminating of waterborne diseases and pathogens (Issa, 2017). The most prevalent issues facing WTPs today are the non-optimized use of chemicals, operation of unit processes, sludge production, and energy consumption (Vieira et al., 2008).

Erbil City in Kurdistan region-Iraq is currently served by two main types of water resources, surface water and groundwater. Surface water is the first significant source of drinking water in Erbil City. There are four WTPs (Ifraz 1, Ifraz 2, Ifraz 3 and Qandil) on Greater-Zab River, three of them are constructed on Greater-Zab River at Ifraz village, and produce with about $60 \%$ of the total drinking water consumed in Erbil City (EWD, 2019). While, Qandil WTP is 
located near Shaqlawa District. However, there are about 1000 deep wells served in Erbil City as a second source of drinking water and they produce about $40 \%$ of the total demand for drinking water (EWD, 2019).

The quality of water, especially the turbidity, varies in winter and summer. The high concentration of turbidity in incoming water into the WTP during the winter season causes problems. Sometimes the WTPs stopped working due to high turbidity. In addition, corrosion due to the use of coagulant is another problem in the mixing coagulant tanks, especially in Ifraz-2 WTP. Furthermore, sometimes some parameters of treated water exceeded drinking water standards. Thus, the aim of this study has been to minimize the effect of quality fluctuations on the operation and performance of WTP units, solve coagulant process problems, and improve the quality of the treated water. In the current work, Ifraz-2 and Qandil WTPs were studied.

The objectives of the proposed work were: 1) To evaluate Greater-Zab River water quality by measuring several parameters, 2) To find optimum settling time, dosage for the coagulants, and PAC) for the adsorption process, and 3 ) To study the cost of the coagulant.

\section{Materials and methods}

\subsection{Greater-zab river water quality}

The Greater-Zab River, shared by Iraq and Turkey, originates from Turkey's Ararat Mountains, passes through the central northern part of Iraq, and then connects to the Tigris River south of Mosul City traversing a distance of 372 $\mathrm{km}$ (Figure 1). Greater-Zab and its tributaries namely Shamdinan, Haji Beg, Rawanduz, and Khazir-Gormal, are situated between latitudes $36^{\circ} \mathrm{N}$ and $38^{\circ} \mathrm{N}$, and longitudes $43.3^{\circ} \mathrm{E}$ and $44.3^{\circ} \mathrm{E}$ (Abbas et al., 2016). It drains an area of $26473 \mathrm{~km}^{2}, 65 \%$ of which is in Iraq and the rest in Turkey (Al-Ansari et al., 2014). The mean annual temperature for Greater-Zab River is $14.3 \mathrm{C}^{\circ}$ and the mean annual rainfall is $570 \mathrm{~mm}$, ranging from $350 \mathrm{~mm}$ to $1000 \mathrm{~mm}$ (Abbas et al., 2016). Grater-Zab River is the only surface water supply accessible for drinking water and other purposes in Erbil City (Shareef and Muhamad, 2008).

An average of two sets of samples per month was collected from November 2018 to April 2019, for both Ifraz-2 and Qandil WTPs. Raw water and treated water samples were gathered in plastic containers and transferred to the Laboratory instantly. They were stored in the refrigerator at $4^{\circ} \mathrm{C}$ before experimental use to prevent biological activities and changes in their characteristics (APHA, 2005).

The collected samples were analyzed for 14 water-quality parameters. These parameters were as follows: Turbidity (NTU), pH, electrical conductivity (EC) $(\mu \mathrm{s} / \mathrm{cm})$, total dissolved solids (TDS) (mg/L), total alkalinity (mg/L), total hardness (mg/L), calcium (Ca) (mg/L), chloride (Cl) $(\mathrm{mg} / \mathrm{L})$, sulphate $\left(\mathrm{SO}_{4}\right)(\mathrm{mg} / \mathrm{L})$, sodium $(\mathrm{Na})(\mathrm{mg} / \mathrm{L})$, potassium $(\mathrm{K})$ $(\mathrm{mg} / \mathrm{L})$, magnesium $(\mathrm{Mg})(\mathrm{mg} / \mathrm{L})$, and nitrate $\left(\mathrm{NO}_{3}\right)(\mathrm{mg} / \mathrm{L})$. In addition, Total coliform (MPN/100 mL) analyzed for treated water. The experiments were carried out in the Laboratory of the Erbil Water Directorate, General
Directorate of Water and Sewerage, Ministry of Municipality and Tourism, Erbil City, Kurdistan region, Iraq.

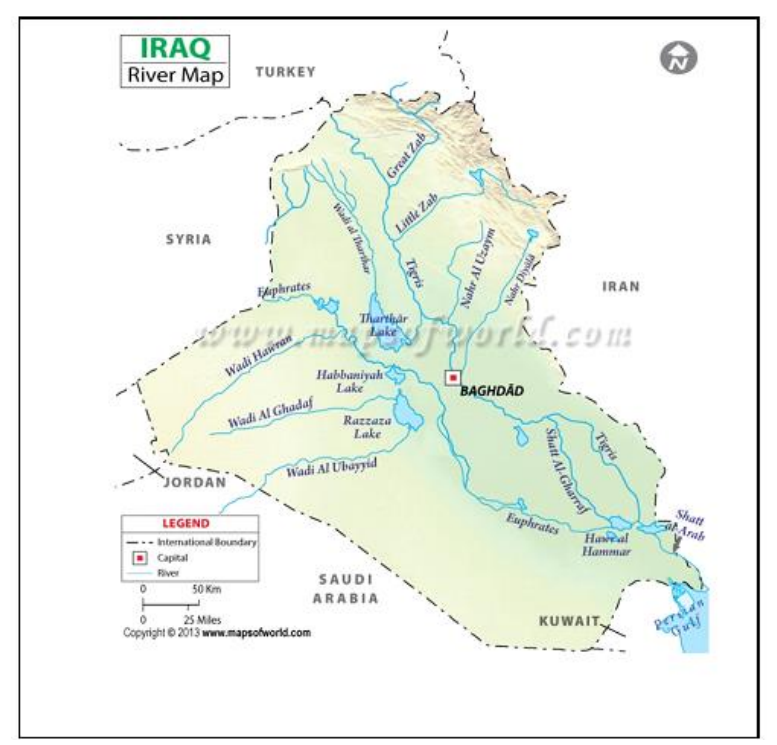

Figure 1. Map of Greater-Zab River.

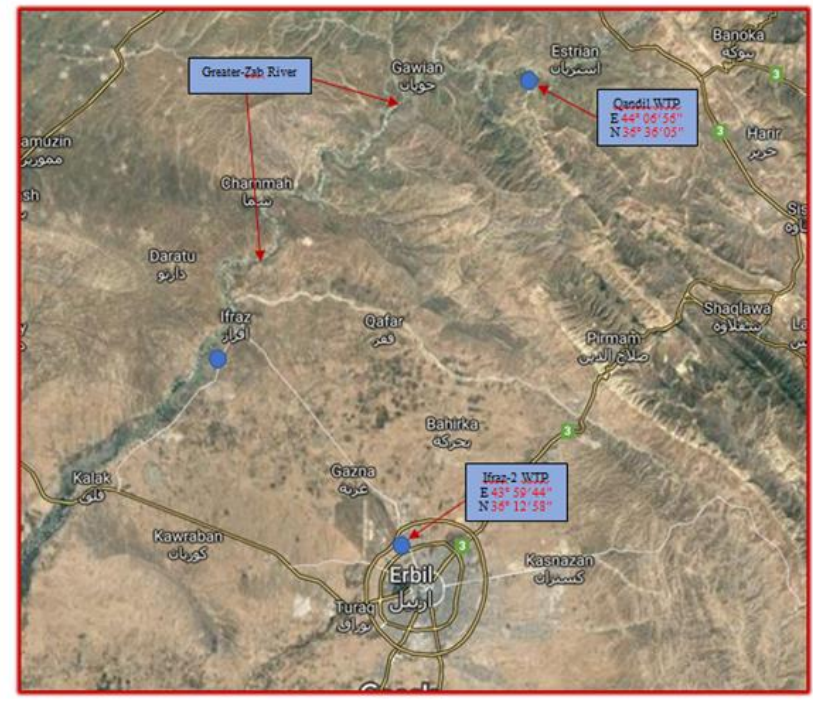

Figure 2. WTPs on Greater-Zab River

\subsection{WTPs}

Ifraz-2 and Qandil WTPs are constructed to treat GreaterZab River water, Figure 2. River water withdrawn by intake structure and conveyed the raw water by a $800 \mathrm{~mm}$ pipe with length of $27.65 \mathrm{~km}$ to Ifraz-2 WTP in Erbil City. While, intake structure and the units for the Qandil WTP are located on the Greater-Zab River. Details of Ifraz-2 and Qandil WTPs are given in Table 1.

\subsection{Optimization of parameters}

Optimization of coagulant dosage, a settling time, and PAC are shown in the following sections.

\subsubsection{Coagulants}

The most commonly used aluminum coagulant is aluminum sulfate. It is available in a number of solid forms such as block, kibbled or ground and can also be used as a solution. In waterworks, aluminum sulfate is often referred to as ' alum ' but wrongly. The solid form has the composition $\mathrm{Al}_{2}\left(\mathrm{SO}_{4}\right)_{3} \mathrm{xH}_{2} \mathrm{O}$ wherexmay range from 14 to 21 containing 
14 to $18 \% \mathrm{w} / \mathrm{w} \mathrm{Al}_{2} \mathrm{O}_{3}$ (alumina) or 7.5 to $9 \% \mathrm{w} / \mathrm{w} \mathrm{Al}$ (aluminum), depending on the number of molecules of water (x) (Brandt et al., 2017).

Two different types of coagulant alum and $\mathrm{ACH}$ used in the Jar tests, solid alum $\mathrm{Al}_{2}\left(\mathrm{SO}_{4}\right)_{3}{ }_{18} \mathrm{H}_{2} \mathrm{O}$, which is already used in Ifraz-2 WTP and alum with polymer are used in Qandil WTP. The general formula of $\mathrm{ACH}\left(\mathrm{Al}(\mathrm{OH})_{\mathrm{m}} \mathrm{Cl}(3 n-\mathrm{m})\right)_{x}$ and have a polymeric structure, totally soluble in water. The length of the polymerized chain, molecular weight and

Table 1. Details of Ifraz-2 and Qandil WTPs (EWD, 2019) number of ionic charges is determined by the degree of polymerization.

Aluminum Chlorohydrate ( $\mathrm{ACH}, \mathrm{n}=2$ and $\mathrm{m}=5$ ).

An important property of $\mathrm{ACH}$ is its basicity. This is the ratio of hydroxyl to aluminum ions in the hydrated complex and in general the higher the basicity, the lower will be the consumption of alkalinity in the treatment process and hence impact on $\mathrm{pH}$. $\mathrm{ACH}$ is selected for this study according to the chemical properties and some advantages of using $\mathrm{ACH}$ as the following:

\begin{tabular}{|c|c|c|c|c|c|c|c|c|}
\hline No. & WTP name & $\begin{array}{c}\text { Year of } \\
\text { built }\end{array}$ & Area of service & $\begin{array}{l}\text { Place of } \\
\text { project }\end{array}$ & $\begin{array}{l}\text { Location of } \\
\text { the Projects }\end{array}$ & $\begin{array}{l}\text { Primary } \\
\text { design } \\
\text { capacity } \\
\left(\mathrm{m}^{3} / \text { day }\right)\end{array}$ & $\begin{array}{l}\text { Designed } \\
\text { capacity } \\
\left(\mathrm{m}^{3} / \text { day }\right)\end{array}$ & $\begin{array}{r}\text { Produced } \\
\text { Capacity } \\
\left(\mathrm{m}^{3} / \text { day }\right)\end{array}$ \\
\hline \multirow{4}{*}{1} & \multirow{4}{*}{ Ifraz-2 } & \multirow{4}{*}{1983} & \multirow{4}{*}{ Erbil-City } & \multirow{4}{*}{ Erbil-City } & $\begin{array}{c}\text { Longitude, } \\
\text { E } \\
\end{array}$ & \multirow{4}{*}{69120} & \multirow{4}{*}{69120} & \multirow{4}{*}{44000} \\
\hline & & & & & $43^{\circ} 59^{\prime} 44^{\prime \prime}$ & & & \\
\hline & & & & & Latitude $\mathrm{N}$ & & & \\
\hline & & & & & $36^{\circ} 12^{\prime} 58^{\prime \prime}$ & & & \\
\hline \multirow{4}{*}{2} & \multirow{4}{*}{ Qandil } & \multirow{4}{*}{2013} & \multirow{4}{*}{$\begin{array}{l}\text { Shaqlawa District } \\
\text { and Salahaddin } \\
\text { sub-District }\end{array}$} & \multirow{4}{*}{$\begin{array}{l}\text { Makerdan } \\
\text { village }\end{array}$} & $\begin{array}{c}\text { Longitude, } \\
\text { E } \\
\end{array}$ & \multirow{4}{*}{64800} & \multirow{4}{*}{120000} & \multirow{4}{*}{64800} \\
\hline & & & & & $44^{\circ} 06^{\prime} 56^{\prime \prime}$ & & & \\
\hline & & & & & Latitude $\mathrm{N}$ & & & \\
\hline & & & & & $36^{\circ} 36^{\prime} 05^{\prime \prime}$ & & & \\
\hline
\end{tabular}

Table 2. PAC Specifications (www.world.taobao.com)

\begin{tabular}{ccc}
\hline Properties & Unit & Descriptions and values \\
\hline Appearance & - & Black fine powder \\
Application & - & $\begin{array}{c}\text { All kinds of water plants, sewage treatment plants, pharmaceutical } \\
\text { industry, food industry, chemical additives, purification, deodorant, } \\
\text { cleaning and so on }\end{array}$ \\
\hline Water soluble content & $\%$ & 5 max. \\
\hline lodine value & $\mathrm{mg} / \mathrm{g}$ & $850-950$ min. \\
\hline Methylene blue adsorbate & $\mathrm{mg} / \mathrm{g}$ & $130-180$ \\
\hline Surface area & $\mathrm{m}^{2} / \mathrm{g}$ & 2000 \\
\hline \% Degree of fineness through 80 mesh & $0.177 \mathrm{~mm}$ & 10 \\
\hline size & & 10 \\
\hline \% Degree of fineness (100 mesh size) & $0.154 \mathrm{~mm}$ & 20 \\
\hline \% Degree of fineness (300 mesh size) & $0.074 \mathrm{~mm}$ & 20 \\
\hline
\end{tabular}

This salt also have a number of additional benefits: it limits aluminum residuals whilst maintaining optimum coagulation properties; it produces stronger and more readily settleable floc than aluminum sulfate, thus reducing the need for polyelectrolytes as coagulant aids; coagulation is less affected by low temperature and produces less sludge than aluminum sulfate (Brandt et al., 2017). ACH2316 is a coagulant with a following property: 1) Odorless, 2) Transparent appearance, 3) Physical state liquid, 4) $\mathrm{pH}$ $(5 \%)=4.1 \pm 0.2,5)$ Aluminum oxide $\left.\left(\mathrm{AL}_{2} \mathrm{O}_{3} \%\right)=23 \pm 0.5,6\right)$ Density $(g / m L)=1.32$, and 7) Relative basicity $(\% \mathrm{w} / \mathrm{w})=82 \%$. Jar test was applied for determining optimum alum and $\mathrm{ACH}$ dosages.

\subsubsection{Settling process}

In the conducted Jar tests, settling time was studied to achieve the optimum settling time in both coagulants. The effect of settling time was studied by allowing the mixers to turn off and the containers were allowed to settle from 1 to 60 minutes. The interval time for settling from $1,5,10$, $15,20,30,40,50$, and 60 minutes used in the experiments to find the optimum settling time. Then the turbidity and the corresponding $\mathrm{pH}$ value of each container was measured at each time, while keeping other parameters such as coagulant dosage, mixing condition, and the time of stirring constant.

\subsubsection{PAC as coagulant aid}

Although PAC is widely used for the removal of organic compounds that cause taste and odor (Kristiana et al., 2011), it was used as a coagulant aid in this study. It is a black fine powder which commercially available and derived from wood or anthracite as raw material by advanced technology; physical and chemical including 
screening, drying with a special production process is refined. After steam activation; refined processing, dewatering, drying and grinding together. The current surface area of PAC that was used in this study about 2000 $\mathrm{m}^{2} / \mathrm{g}$ required from the purchasing company (Taobao Online Shop). The specifications of used PAC are shown in Table 2.

PAC used during the coagulation process in Jar tests as coagulant aid to find its effect on turbidity removal efficiency, while the selection of optimum PAC dosage was based on the best removal efficiencies of turbidity. The amount of PAC which used in the experiment are from $0.05,0.1,0.15,0.2,0.25,0.4$, and $0.5 \mathrm{~g} / \mathrm{L}$ added to each beaker and mixed by a jar test mixer with a constant speed for all beakers. To determine optimum PAC dosage, the removal efficiency of turbidity was determined.

\section{Results and discussions}

\subsection{Greater-zab river water characteristics}

The collected samples were tested for thirteen parameters. The results of the characteristics of raw water near Ifraz-2 and Qandil WTPS are listed in Tables 3 and 4. Turbidity value ranged between 17 to 705 NTU and from 13.8 to 826 NTU for both locations, it is over the standard. Since turbidity values were greater than the WHO standard for the drinking water, the treatment processes are essential for the Greater Zab River water to adjust the turbidity values to the acceptable levels to supply potable and safe water to the consumers.

Table 3. Results of raw water at Ifraz 2 WTP

\begin{tabular}{|c|c|c|c|c|c|c|c|c|c|c|c|c|c|c|}
\hline No. & Date & Turbidity & $\mathrm{pH}$ & EC & TDS & \begin{tabular}{|c} 
Totla \\
Alkalini \\
ty
\end{tabular} & $\begin{array}{c}\text { Total } \\
\text { Hardness }\end{array}$ & $\mathrm{Ca}^{++}$ & $\mathrm{Cl}^{-}$ & $\mathrm{SO}_{4^{--}}$ & $\mathrm{Mg}^{++}$ & $\mathrm{Na}^{+}$ & $\mathbf{K}^{+}$ & $\mathrm{NO}_{3-}$ \\
\hline 1 & $12 / 11 / 2018$ & 121 & 7.80 & 356 & 231.4 & 212 & 314 & 79 & 9 & 26 & 56.4 & 10 & 1.1 & 9 \\
\hline 2 & $21 / 11 / 2018$ & 55.5 & 7.86 & 366 & 237.9 & 203 & 288 & 72 & 12 & 27 & 51.84 & 9 & 1 & 8.25 \\
\hline 3 & $02 / 12 / 2018$ & 419 & 8.20 & 376 & 244.4 & 198 & 310 & 78 & 16 & 62 & 55.68 & 10 & 1.8 & 9 \\
\hline 4 & $18 / 12 / 2018$ & 62.5 & 7.80 & 373 & 242.45 & 201 & 254 & 64 & 9 & 28 & 45.6 & 10 & 1.1 & 9 \\
\hline 5 & $05 / 01 / 2019$ & 89 & 7.83 & 384 & 249.6 & 205 & 262 & 66 & 11 & 36 & 47.04 & 10 & 1.2 & 6 \\
\hline 6 & $23 / 1 / 2019$ & 13.8 & 7.87 & 439 & 285.35 & 219 & 268 & 67 & 10 & 47 & 48.24 & 9 & 1 & 3 \\
\hline 7 & $04 / 02 / 2019$ & 58.1 & 7.80 & 396 & 257.4 & 211 & 300 & 75 & 10 & 39 & 54 & 6 & 0.8 & 3.75 \\
\hline 8 & $12 / 02 / 2019$ & 49.5 & 7.7 & 392 & 254.8 & 208 & 290 & 73 & 12 & 31 & 52.08 & 5 & 0.7 & 4.25 \\
\hline 9 & $04 / 03 / 2019$ & 48.5 & 7.7 & 392 & 254.8 & 201 & 300 & 75 & 8 & 47 & 54 & 10 & 0.9 & 4.5 \\
\hline 10 & $25 / 3 / 2019$ & 110 & 7.1 & 424 & 275.6 & 186 & 308 & 77 & 11 & 56 & 55.44 & 14 & 2.1 & 4.5 \\
\hline 11 & $01 / 04 / 2019$ & 300 & 7.9 & 372 & 241.8 & 194 & 305 & 76 & 7 & 25 & 54.96 & 7 & 1.3 & 4.75 \\
\hline 12 & $22 / 4 / 2019$ & 826 & 7.80 & 330 & 214.5 & 186 & 292 & 73 & 13 & 36 & 52.56 & 6 & 0.9 & 2.5 \\
\hline \multirow{2}{*}{ 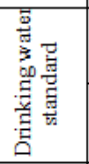 } & (WHO, 2011) & 5 & $6.5-9.5$ & 1000 & 500 & 200 & 200 & 200 & 250 & 200 & 30 & 200 & 10 & 50 \\
\hline & $\begin{array}{c}\text { Iraqi Standard } \\
1986\end{array}$ & Less than 10 & $6.5-8.5$ & 1000 & 600 & 200 & 500 & 200 & 250 & 400 & 50 & 200 & $\mathrm{~N} / \mathrm{A}$ & 45 \\
\hline 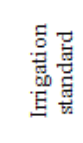 & $\begin{array}{c}\text { (Medcalf and } \\
\text { Eddy, 2014), } \\
\text { (Ayers and } \\
\text { Westcot, 1985) }\end{array}$ & $\mathrm{N} / \mathrm{A}$ & $6.5-8.4$ & $<700$ & $<450$ & $\mathrm{~N} / \mathrm{A}$ & $\mathrm{N} / \mathrm{A}$ & $\mathrm{N} / \mathrm{A}$ & $\mathrm{N} / \mathrm{A}$ & $\mathrm{N} / \mathrm{A}$ & $\mathrm{N} / \mathrm{A}$ & $\mathrm{N} / \mathrm{A}$ & $\mathrm{N} / \mathrm{A}$ & $5-30$ \\
\hline 总 & $\begin{array}{l}\text { (Kucche et al., } \\
2015 \text { ) }\end{array}$ & N/A & $\geq 6$ & $\mathrm{~N} / \mathrm{A}$ & $\mathrm{N} / \mathrm{A}$ & $\mathrm{N} / \mathrm{A}$ & $\mathrm{N} / \mathrm{A}$ & $\mathrm{N} / \mathrm{A}$ & $\begin{array}{l}\leq 500 \\
\mathrm{mg} / \mathrm{L}\end{array}$ & $\begin{array}{l}\leq 500 \\
\mathrm{mg} / \mathrm{L}\end{array}$ & $\mathrm{N} / \mathrm{A}$ & $\mathrm{N} / \mathrm{A}$ & $\mathrm{N} / \mathrm{A}$ & $\mathrm{N} / \mathrm{A}$ \\
\hline
\end{tabular}

The $\mathrm{pH}$ values exceed 7.5 in most cases. This may be attributed to the erosion of carbonate ions from soils, and waters were in the alkaline $\mathrm{pH}$ range without remarkable variations, which was within the recommended range for drinking water quality standard (WHO, 2011). Also, the $\mathrm{pH}$ values were safe for construction (Kucche et al., 2015). A similar trend of $\mathrm{pH}$ values in different branches of GreaterZab river was recorded by (Aziz, 2008; Toma, 2013; Hanna and Shekha, 2015). The values of $\mathrm{pH}$ were suitable for irrigation purposes according to Ayers and Westcot (1985).

The observed results for water in Greater-Zab showed $\mathrm{Cl}$ content values ranged from $8 \mathrm{mg} / \mathrm{L}$ to $17 \mathrm{mg} / \mathrm{L}$ in Table 4 and 7 to $16 \mathrm{mg} / \mathrm{L}$ in Table 3 . Water quality standards for construction require $\mathrm{Cl}$ concentrations of $500 \mathrm{mg} / \mathrm{L}$ for reinforced concrete, and $2000 \mathrm{mg} / \mathrm{L}$ for plain concrete (Kucche et al., 2015; Aziz et al., 2017). The obtained chloride values show that water in Greater-Zab can be used for construction because the concentrations of chloride were less than $500 \mathrm{mg} / \mathrm{L}$. The concentration of $\mathrm{Cl}$ can be considered as weak water type (< $70 \mathrm{mg} / \mathrm{L}$ ) which is suitable for almost all plants irrigation according to Shekha (2016).

Sulfate figures were ranged between 10 to $92 \mathrm{mg} / \mathrm{L}$ for Ifraz-2 in Table 4, and 25 to $62 \mathrm{mg} / \mathrm{L}$ in Table 3 for Qandil location which are less than the declared standards. Thus, water in Greater-Zab is within permissible level according to water quality standard for Iraqi standard for drinking water and safe for construction (Kucche et al., 2015; Aziz et al., 2017). Also, Sulfate concentration is within the permissible level for irrigation purposes according to (Abbas, 1986; Aziz, 2006).

TDS value ranged from 214.5 to $285.35 \mathrm{mg} / \mathrm{L}$ for Ifraz-2, and from 217.7 to $300.3 \mathrm{mg} / \mathrm{L}$ for Qandil which are within the range of WHO and Iraqi standards for drinking water. A similar trend of TDS was reported by (Aziz, 2008; Shekha, 2016) at the monitored river. The concentration of TDS is entirely safe for irrigation according to Aziz et al. (2017). 
EC for collected samples was ranged from 330 to $439 \mu \mathrm{s} / \mathrm{cm}$ in Ifraz-2 location and from 335 to $462 \mu \mathrm{s} / \mathrm{cm}$ for Qandil location, which are within the standards. Puri et al. (2015) in Nagpur city, Maharashtra India, indicated that the greater values in the rainy season could be due to surface runoff from the surrounding areas that might have brought in ionic substances such as nitrates, chlorides, and phosphates from fertilizers. A similar trend of results has been noted by (Aziz, 2008; Kafia et al., 2009; Shekha, 2016). The concentration of EC is falling in good class for irrigation according to Aziz et al. (2017).

Total Alkalinity for collected samples ranged from 186 to $219 \mathrm{mg} / \mathrm{L}$ in Ifraz-2 and from 161 to $236 \mathrm{mg} / \mathrm{L}$ which was above WHO and Iraqi standards for drinking water.

Total Hardness are ranged between 254 to $314 \mathrm{mg} / \mathrm{L}$ in Ifraz-2, and from 246 to $380 \mathrm{mg} / \mathrm{L}$ in Qandil location which are above the WHO standard, but within Iraqi standard as mentioned in Tables 3 and 4 . The results obtained by Toma (2013) showed that total hardness values were often higher than the minimum permissible level recommended by the WHO for drinking water.

The concentration of $\mathrm{Ca}, \mathrm{Cl}, \mathrm{SO}_{4}, \mathrm{Na}, \mathrm{K}$, and $\mathrm{NO}_{3}$ for water samples from Greater-Zab River are within (WHO, 2011) and Iraqi standard. A similar trend observed by Shekha (2016).

$\mathrm{Mg}$ for collected samples was ranged from 45.6 to 56.4 $\mathrm{mg} / \mathrm{L}$ near Ifraz-2, and from 44.1 to $68.4 \mathrm{mg} / \mathrm{L}$ near Qandil, which exceeded WHO and Iraqi standards. Shekha (2016) observed $\mathrm{Mg}$ values exceeding the permissible range, while the values of $\mathrm{Mg}$ which reported by Toma (2013) were within the WHO and Iraqi standard. It is obvious from the reported data that the Greater-Zab River quality needs treatment before using and not safe for drinking, but it is safe for construction and irrigation.

Table 4. Results of raw water at Qandil WTP

\begin{tabular}{|c|c|c|c|c|c|c|c|c|c|c|c|c|c|c|}
\hline No. & Date & Turbidity & $\mathrm{pH}$ & EC & TDS & \begin{tabular}{|c|} 
Totlal \\
Alkalini \\
ty
\end{tabular} & $\begin{array}{c}\text { Total } \\
\text { Hardness }\end{array}$ & $\mathrm{Ca}^{++}$ & Cl- & $\mathrm{SO}_{4}{ }^{--}$ & $\mathrm{Na}^{+}$ & $\mathbf{K}^{+}$ & $\mathrm{Mg}^{++}$ & $\mathrm{NO}_{3}-$ \\
\hline 1 & $09 / 11 / 2018$ & 375 & 7.5 & 432 & 280.8 & 195 & 300 & 75 & 13 & 65 & 13 & 1.1 & 54 & 9 \\
\hline 2 & $29 / 11 / 2018$ & 640 & 7.11 & 360 & 234 & 161 & 292 & 73 & 12 & 45 & 12 & 1.2 & 52.56 & 13 \\
\hline 3 & $17 / 12 / 2018$ & 142 & 7.7 & 393 & 255.45 & 219 & 246 & 62 & 8 & 38 & 8 & 1 & 44.16 & 10 \\
\hline 4 & $27 / 12 / 2018$ & 81.5 & 7.8 & 420 & 273 & 236 & 290 & 73 & 17 & 44 & 11 & 1.1 & 52.08 & 11 \\
\hline 5 & $06 / 01 / 2019$ & 17 & 7.8 & 425 & 276.25 & 207 & 380 & 95 & 10 & 10 & 8 & 1 & 68.4 & 12 \\
\hline 6 & $27 / 1 / 2019$ & 25.2 & 7.7 & 430.0 & 279.5 & 228.0 & 290.0 & 73.0 & 12.0 & 49.0 & 10.0 & 1.1 & 52.08 & 2.5 \\
\hline 7 & $17 / 2 / 2019$ & 460 & 7.6 & 406 & 263.9 & 215 & 290 & 73 & 10 & 59 & 8 & 1.1 & 52.08 & 4.75 \\
\hline 8 & $26 / 2 / 2019$ & 51.2 & 7 & 462 & 300.3 & 185 & 339 & 85 & 11 & 18 & 21 & 2.2 & 60.96 & 5.5 \\
\hline 9 & $04 / 03 / 2019$ & 90.2 & 7.7 & 396 & 257.4 & 204 & 300 & 75 & 12 & 47 & 13 & 1.2 & 54 & 5 \\
\hline 10 & $17 / 3 / 2019$ & 280 & 7.5 & 391 & 254.15 & 245 & 300 & 75 & 12 & 70 & 9 & 1.4 & 54 & 7 \\
\hline 11 & 02/04/2019 & 705 & 7.9 & 339 & 220.35 & 217 & 285 & 71 & 12 & 92 & 29 & 1.2 & 51.36 & 7 \\
\hline 12 & $23 / 4 / 2019$ & 40.5 & 7.6 & 335 & 217.75 & 212 & 340 & 85 & 11 & 38 & 29.2 & 1.4 & 61.2 & 3.5 \\
\hline \multirow{2}{*}{ 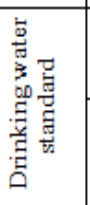 } & (WHO, 2011) & 5 & $6.5-9.5$ & 1000 & 500 & 200 & 200 & 200 & 250 & 200 & 200 & 10 & 30 & 50 \\
\hline & $\begin{array}{c}\text { Iraqi Standard } \\
1986\end{array}$ & Less than 10 & $6.5-8.5$ & 1000 & 600 & 200 & 500 & 200 & 250 & 400 & 200 & $\mathrm{~N} / \mathrm{A}$ & 50 & 45 \\
\hline 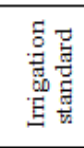 & $\begin{array}{l}\text { (Medcalf and } \\
\text { Eddy, 2014), } \\
\text { (Ayers and } \\
\text { Westcot, 1985) }\end{array}$ & $\mathrm{N} / \mathrm{A}$ & $6.5-8.4$ & $<700$ & $<450$ & $\mathrm{~N} / \mathrm{A}$ & $\mathrm{N} / \mathrm{A}$ & $\mathrm{N} / \mathrm{A}$ & $\mathrm{N} / \mathrm{A}$ & $\mathrm{N} / \mathrm{A}$ & $\mathrm{N} / \mathrm{A}$ & $\mathrm{N} / \mathrm{A}$ & $\mathrm{N} / \mathrm{A}$ & $5-30$ \\
\hline 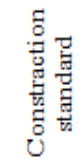 & $\begin{array}{l}\text { (Kucche et al., } \\
\text { 2015) }\end{array}$ & $\mathrm{N} / \mathrm{A}$ & 26 & $\mathrm{~N} / \mathrm{A}$ & $\mathrm{N} / \mathrm{A}$ & $\mathrm{N} / \mathrm{A}$ & $\mathrm{N} / \mathrm{A}$ & $\mathrm{N} / \mathrm{A}$ & $\begin{array}{l}\leq 500 \\
\mathrm{mg} / \mathrm{L}\end{array}$ & $\begin{array}{l}\leq 500 \\
\mathrm{mg} / \mathrm{L}\end{array}$ & $\mathrm{N} / \mathrm{A}$ & $\mathrm{N} / \mathrm{A}$ & $\mathrm{N} / \mathrm{A}$ & $\mathrm{N} / \mathrm{A}$ \\
\hline
\end{tabular}

During the study according to the collected data for both stations. In general, all the parameters from Ifraz-2 station were higher than in Qandil station except for $\mathrm{pH}$ parameter which shown in Figure 3, which include the mean values for all the parameter tested during the study period.

There are significant variations between the value of turbidity in the two places. Depending on the site investigations there are two main reasons for the high turbidity of Ifraz-2 location compare with Qandil location. The first reason was because of Bastora tributary which feeds Greater-Zab River in the rainy season which effect on the raw water at Ifraz-2 station, and the second reason due to existing some Quarries of sand and gravel at Greater-Zab river near Ifraz-2 station which increased the turbidity in Ifraz station.

EC is a measurement for the ability of water to conduct an electrical current. The ability is a result of the presence of ions in water such as $\mathrm{Ca}, \mathrm{Cl}, \mathrm{SO}_{4}, \mathrm{Na}, \mathrm{K}$, and $\mathrm{Mg}$ (Shekha, 2016), these ions at Ifraz-2 station were greater than at Qandil station, consequence to EC at Ifraz-2 station higher than EC at Qandil station. The high concentration of $\mathrm{Mg}$ and 
Ca at Ifraz-2 station compare to Qandil station led to higher total hardness at Ifraz-2 station.

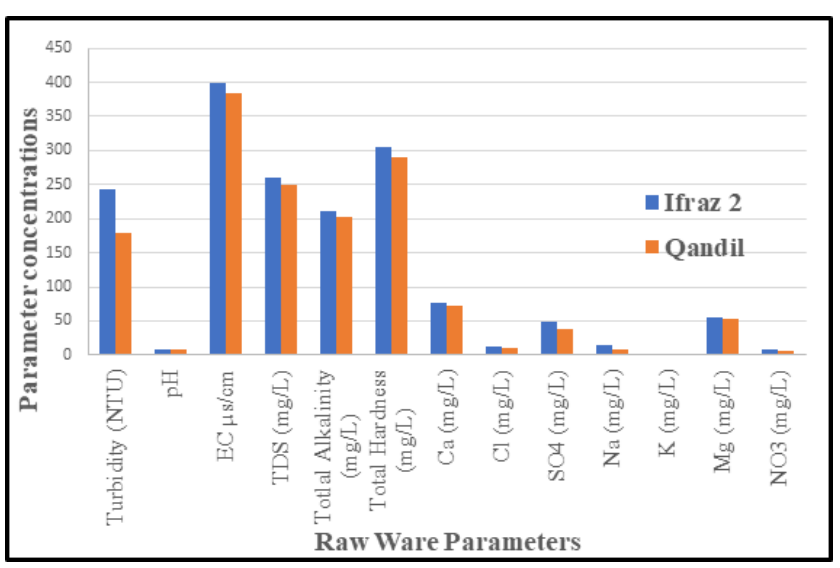

Figure 3. Mean values of the parameters in Ifraz-2 and Qandil stations.

\subsection{Optimization of parameters for coagulation process}

During the study period coagulants, settling time, and PAC dosage were studied and optimized by conducting Jar tests.

\subsubsection{Coagulants}

The efficiency of $\mathrm{ACH}$ and alum through conducting nineteen Jar tests are studied comparatively in this work. The minimum and the maximum raw water turbidity for the samples used in the experiments were 111 NTU and
4600 NTU. The removal of suspended solids and the optimum dosage for each coagulant were carefully monitored and they are used for the evaluation of effectiveness for each coagulant, as well as for the determination of optimal operative conditions.

Table 5 presents a sample of conducting the Jar test for 1000 NTU raw water sample. The optimum dosage of alum was $60 \mathrm{mg} / \mathrm{L}$, while the optimum dosage of $\mathrm{ACH}$ was 11.5 $\mu \mathrm{l} / \mathrm{L}$ for the sample. According to Brandt et al. (2017), the turbidity after sedimentation process must be between 1 to $5 \mathrm{NTU}$, but the turbidity of 7 NTU for both coagulants were selected as optimum dosages due to 30 minutes settling time in conducted Jar tests, while the settling time in the sedimentation tank in the WTP normally ranged between 2 to 3 hours which give us a result of turbidity less than or equal to 5 NTU due to more removal efficiency with more settling time.

From the results of $\mathrm{pH}$ values in conducted Jar test in Table 5 , the value of $\mathrm{pH}$ was decreased with increasing of alum dosage, while the value of $\mathrm{pH}$ was increased with increasing of $\mathrm{ACH}$ dosage because of high basicity, this status also mentioned by (Brandt et al., 2017).

The optimum dosage of coagulants in the jar tests started from 12.5 to $210 \mathrm{mg} / \mathrm{L}$ for Alum, and from 2.5 to $50(\mu \mathrm{l} / \mathrm{L})$ for ACH coagulant. Table 6 shows a summary of optimum alum and $\mathrm{ACH}$ results for different turbidities of $19 \mathrm{Jar}$ tests.

Table 5. The optimum dosage of alum and ACH for raw water turbidity of 1000 NTU conducted on 18-3-2019

\begin{tabular}{|c|c|c|c|c|c|c|c|c|c|c|c|c|c|}
\hline & & \multicolumn{6}{|c|}{ Jar test using alum (mg/L) } & \multicolumn{6}{|c|}{ Jar test using $\mathrm{ACH}(\mu \mathrm{l} / \mathrm{L})$} \\
\hline & & Alum & Alum & Alum & Alum & Alum & Alum & $\mathrm{ACH}$ & $\mathrm{ACH}$ & $\mathrm{ACH}$ & $\mathrm{ACH}$ & $\mathrm{ACH}$ & $\mathrm{ACH}$ \\
\hline \multicolumn{2}{|c|}{ Coagulant dosage } & 30 & 40 & 50 & 60 & 70 & 80 & 8 & 10 & 11 & 11.5 & 14 & 16 \\
\hline $\begin{array}{l}\text { Rapid mix } \\
\text { speed }\end{array}$ & (rpm) & 100 & 100 & 100 & 100 & 100 & 100 & 100 & 100 & 100 & 100 & 100 & 100 \\
\hline $\begin{array}{l}\text { Rapid mix } \\
\text { duration }\end{array}$ & $(\min )$. & 1 & 1 & 1 & 1 & 1 & 1 & 1 & 1 & 1 & 1 & 1 & 1 \\
\hline Slow mix speed & (rpm) & 20 & 20 & 20 & 20 & 20 & 20 & 20 & 20 & 20 & 20 & 20 & 20 \\
\hline $\begin{array}{l}\text { Slow mix } \\
\text { duration }\end{array}$ & $(\min )$. & 20 & 20 & 20 & 20 & $20^{\prime}$ & 20 & 20 & 20 & 20 & 20 & 20 & 20 \\
\hline $\begin{array}{l}\text { Sedimentation } \\
\text { Period }\end{array}$ & $(\min )$. & 30 & 30 & 30 & 30 & 30 & 30 & 30 & 30 & 30 & 30 & 30 & 30 \\
\hline $\mathrm{pH}$ & 7.43 & 7.27 & 7.24 & 7.22 & 7.20 & 7.22 & 7.20 & 7.25 & 7.25 & 7.32 & 7.36 & 7.32 & 7.36 \\
\hline Turbidity & NTU & 17.0 & 13.4 & 9.0 & 7.0 & 4.5 & 3.8 & 14.2 & 11.3 & 8.7 & 7.0 & 4.6 & 3.3 \\
\hline
\end{tabular}

From the data in Table 6, the prediction equation of the relationship between raw water turbidity and alum optimum dosage is:

$$
Y=0.04 x+14.42
$$

as shown in Figure 4.

Where: -

$\mathrm{Y}=$ alum optimum dosage $(\mathrm{mg} / \mathrm{L})$

$\mathrm{X}=$ raw water turbidity (NTU)

The relation between raw water turbidity verses alum optimum dosage as shown in Figure 4.
The prediction equation between raw water turbidity and $\mathrm{ACH}$ optimum dosage is as shown in Figure 5 as the following:

$$
Y=0.01 x+0.72
$$

Where: -

$$
\begin{aligned}
& \mathrm{Y}=\mathrm{ACH} \text { optimum dosage }(\mathrm{mg} / \mathrm{L}) \\
& \mathrm{X}=\text { raw water turbidity (NTU) }
\end{aligned}
$$

Figure 6 explained the different weight between alum and $\mathrm{ACH}$ for different raw water turbidity. In all cases weight of alum is more than weight of $\mathrm{ACH}$. 
From the results of 19 conducted Jar Tests, it concluded that there are some advantages of using $\mathrm{ACH}$ instead of alum as the following:

I. By using $\mathrm{ACH}$ products, do not need to make solutions as an alum. $\mathrm{ACH}$ is liquid, because of that it does not need a mixer and not need manpower.

II. Ease of use, less dangerous product, and friendly with the environment.

III. ACH easy for storage and dosing.

IV. By using $\mathrm{ACH}$, the overall coagulant use will reduce, this means a reduction of the used energy for dosage pumps compare with alum coagulant.

V. Residual Aluminum rate is always less than the value of the world standard according to WHO by using ACH (Brandt et al., 2017).

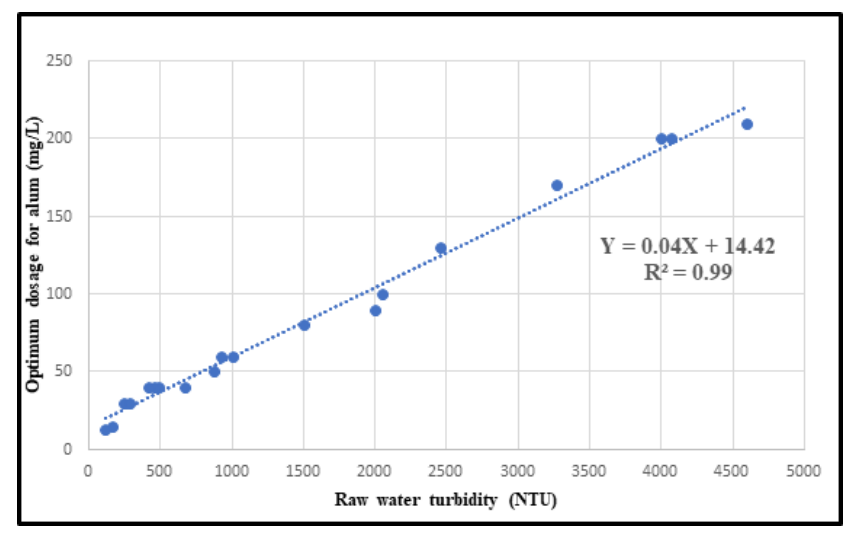

Figure 4. The model prediction between alum and raw water turbidity

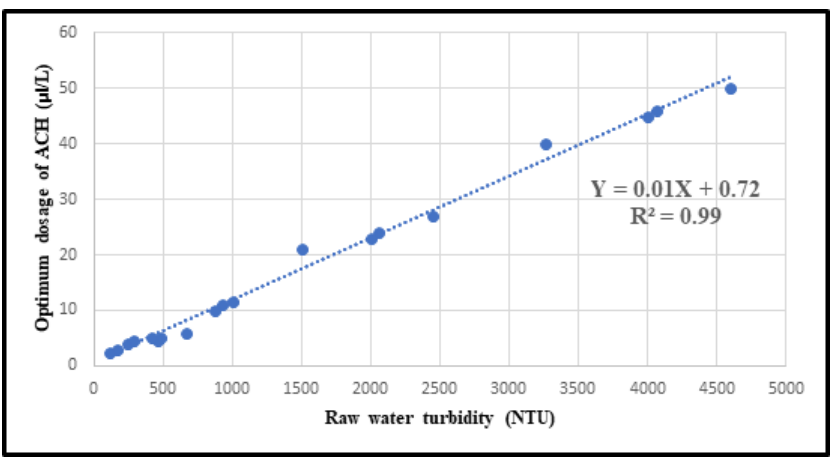

Figure 5. The model prediction between $\mathrm{ACH}$ and raw water turbidity.

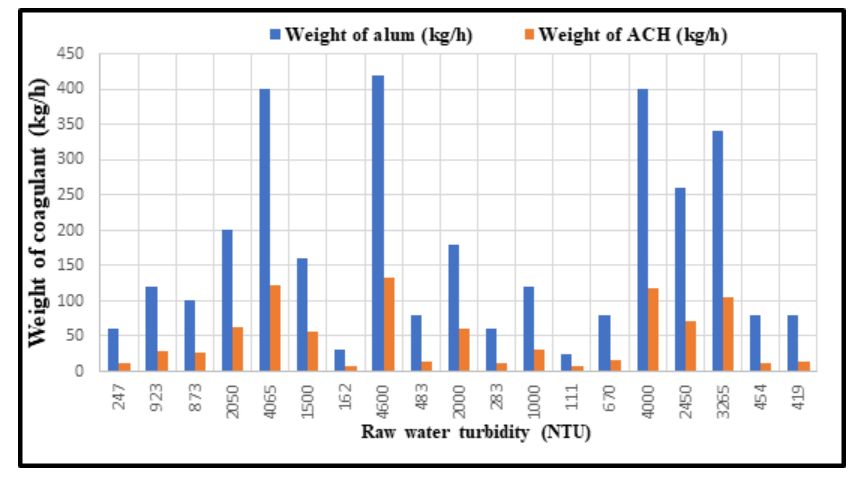

Figure 6. Coagulant weight with different raw water turbidity.

\subsubsection{Settling time}

The optimum settling time by using optimum dosages of alum and $\mathrm{ACH}$ coagulants were studied by conducting Jar tests with varies settling times from 1 to $60 \mathrm{~min}$ for raw water turbidities of 1000 and 2000 NTU as shown in Table 7.

The reduction of turbidity was measured each time while keeping the optimum dosage of the coagulant. The effect of settling time on the reduction of turbidity was illustrated in Figures 7 and 8.

The results showed that $30 \mathrm{~min}$. and $40 \mathrm{~min}$. are the optimum settling time for 1000 and 2000 NTU, respecttively since the result remained with few changes.

It is obvious from Figures 7 and 8 that the settling time for $\mathrm{ACH}$ in the first ten minutes was very speed, this is due high effective of $\mathrm{ACH}$ coagulant in which generated the flocs in bigger sizes and led to fast settling.

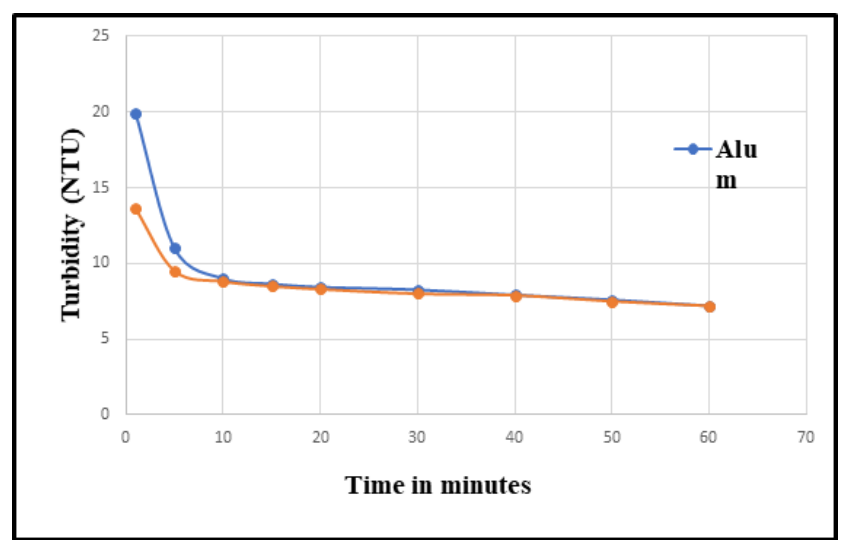

Figure 7. Settling time using alum and ACH for 1000 NTU turbidity

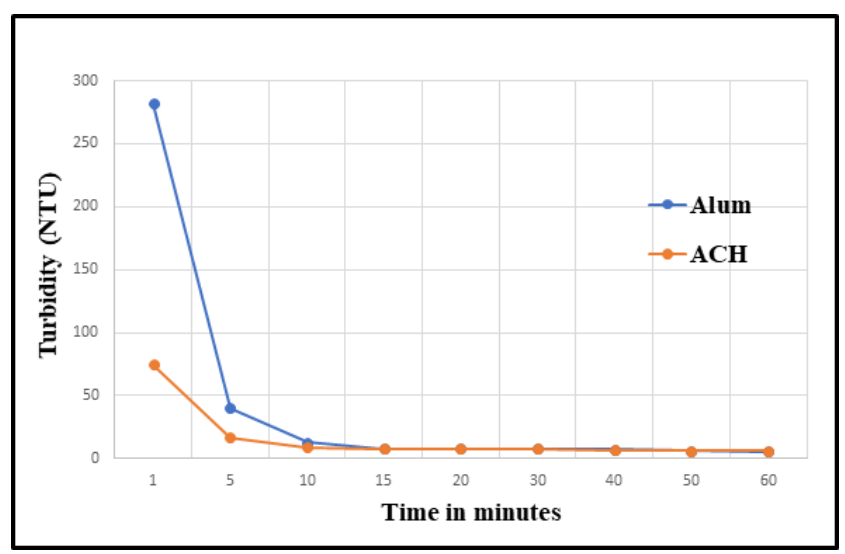

Figure 8. Settling time using alum and ACH for 2000 NTU turbidity

\subsection{3. $P A C$}

The turbidity of the sample, optimum alum dosage, and sedimentation time were kept constant for determination of optimum PAC dosage. The selection of optimum PAC dosage was based on the optimum removal of turbidity for each dosage. 
The concentration and removal of suspended solids are illustrated in Table 8 for two different raw water turbidity samples 419 and 1000 NTU because in other parameters like optimum coagulants and settling time the same raw water turbidity of 1000 NTU were used. In addition, the sample with 419 NTU also optimized to determine PAC efficiency in more than one sample to confirm the effect of the PAC on turbidity removal.

Table 6. A summary of optimum alum and $\mathrm{ACH}$ results for different turbidities

\begin{tabular}{|c|c|c|c|c|c|c|}
\hline No. & Date of Test & $\mathrm{pH}$ & $\begin{array}{c}\text { Temperature } \\
\mathbf{C}^{\circ} \\
\end{array}$ & $\begin{array}{c}\text { Turbidity of Raw } \\
\text { water (NTU) }\end{array}$ & $\begin{array}{l}\text { Optimum dosage of alum } \\
\text { from Jar Tests (mg/L) }\end{array}$ & $\begin{array}{c}\text { Optimum dosage of } \mathrm{ACH} \\
\text { from Jar Tests }(\mu \mathrm{l} / \mathrm{L})\end{array}$ \\
\hline 1 & $02 / 01 / 2019$ & 7.49 & 11.7 & 247 & 30 & 4 \\
\hline 2 & 20/1/2019 & 7.00 & 13.8 & 923 & 60 & 11 \\
\hline 3 & $21 / 01 / 2019$ & 7.11 & 13.6 & 873 & 50 & 10 \\
\hline 4 & $23 / 1 / 2019$ & 7.16 & 14.2 & 2050 & 100 & 24 \\
\hline 5 & $27 / 1 / 2019$ & 7.21 & 12.1 & 4065 & 200 & 46 \\
\hline 6 & $30 / 1 / 2019$ & 7.08 & 14.3 & 1500 & 80 & 21 \\
\hline 7 & $05 / 02 / 2019$ & 6.94 & 13.1 & 162 & 15 & 3 \\
\hline 8 & $06 / 02 / 2019$ & 7.00 & 12.6 & 4600 & 210 & 50 \\
\hline 9 & $27 / 02 / 2019$ & 7.22 & 11.7 & 483 & 40 & 5 \\
\hline 10 & $04 / 03 / 2019$ & 7.24 & 13.6 & 2000 & 90 & 23 \\
\hline 11 & $17 / 3 / 2019$ & 7.61 & 12.8 & 283 & 30 & 4.5 \\
\hline 12 & $18 / 3 / 2019$ & 7.33 & 12.2 & 1000 & 60 & 11.5 \\
\hline 13 & $25 / 3 / 2019$ & 7.43 & 15.4 & 111 & 12.5 & 2.5 \\
\hline 14 & $04 / 04 / 2019$ & 7.71 & 18.7 & 670 & 40 & 6 \\
\hline 15 & $08 / 04 / 2019$ & 7.31 & 18.7 & 4000 & 200 & 45 \\
\hline 16 & $09 / 04 / 2019$ & 7.31 & 19.5 & 2450 & 130 & 27 \\
\hline 17 & $12 / 04 / 2019$ & 7.45 & 20.2 & 3265 & 170 & 40 \\
\hline 18 & $13 / 4 / 2019$ & 7.10 & 21.8 & 454 & 40 & 4.5 \\
\hline 19 & $17 / 04 / 2019$ & 7.00 & 22 & 419 & 40 & 5 \\
\hline
\end{tabular}

Table 7. Settling time for alum and $\mathrm{ACH}$ coagulants

\section{No. Interval of settling time in minutes}

Initial Turbidity of 1000 NTU

Turbidity (NTU) by using optimum dosages of alum and $\mathrm{ACH}$
Initial Turbidity of 2000 NTU

Turbidity (NTU) by using optimum dosages of alum and $\mathrm{ACH}$

\begin{tabular}{ccccccc} 
& & Alum (60 $\mathbf{~ m g} / \mathbf{L})$ & ACH (11.5 $\boldsymbol{\mu l} / \mathbf{L})$ & Alum (90 $\mathbf{~ m g} / \mathbf{L})$ & ACH (23 $\boldsymbol{\mu l} / \mathbf{L})$ \\
\hline 1 & 1 & 19.9 & 13.6 & 282.0 & 75.0 \\
\hline 2 & 5 & 11.0 & 9.5 & 40.0 & 17.0 \\
\hline 3 & 10 & 9.0 & 8.8 & 13.0 & 9.0 \\
\hline 4 & 15 & 8.6 & 8.5 & 8.0 & 8.0 \\
\hline 5 & 20 & 8.4 & 8.3 & 8.0 & 8.0 \\
\hline 6 & 30 & 8.2 & 8.0 & 7.8 & 7.7 \\
\hline 7 & 40 & 7.9 & 7.9 & 7.1 & 7.0 \\
\hline 8 & 50 & 7.6 & 7.5 & 6.0 & 6.0 \\
\hline 9 & 60 & 7.2 & 7.2 & 5.7 & 6.0 \\
\hline
\end{tabular}

Table 8. The effect of adding PAC to coagulant on turbidity

\begin{tabular}{ccccccc}
\hline $\begin{array}{c}\text { PAC } \\
\text { dosage } \\
\text { (g/L) }\end{array}$ & \multicolumn{2}{c}{ Raw water turbidity=419 NTU } & \multicolumn{3}{c}{ Raw water turbidity=1000 NTU } \\
\cline { 2 - 7 } & $\begin{array}{c}\text { Optimum alum } \\
\text { dosage (mg/L) }\end{array}$ & $\begin{array}{c}\text { Turbidity } \\
\text { after Jar test }\end{array}$ & $\begin{array}{c}\text { Removal efficiency } \\
\text { of PAC } \%\end{array}$ & $\begin{array}{c}\text { Optimum alum } \\
\text { dosage (mg/L) }\end{array}$ & $\begin{array}{c}\text { Turbidity after } \\
\text { Jar test }\end{array}$ & $\begin{array}{c}\text { Removal efficiency } \\
\text { of PAC \% }\end{array}$ \\
\hline 0 & 40 & 6.84 & 0.00 & 60 & 7 & 0.00 \\
\hline 0.05 & 40 & 4.98 & 27.19 & 60 & 6.4 & 8.57 \\
\hline 0.1 & 40 & 4.86 & 28.95 & 60 & 6.2 & 11.43 \\
\hline 0.15 & 40 & 4.91 & 28.22 & 60 & 6 & 14.29 \\
\hline 0.2 & 40 & 4.97 & 27.34 & 60 & 5.75 & 17.86 \\
\hline 0.25 & 40 & 5.1 & 25.44 & 60 & 5.2 & 25.71 \\
\hline 0.4 & 40 & 5.4 & 21.01 & 60 & 5.4 & 22.86 \\
\hline 0.5 & 40 & 6.9 & -0.88 & 60 & 7 & 0.00 \\
\hline
\end{tabular}

Alum and $\mathrm{ACH}$ coagulants were used in the experiments, but PAC only works with alum and increased the removal efficiency of suspended solids in the samples, while the removal efficiency was decreased with $\mathrm{ACH}$. This is due to the interactions between $\mathrm{ACH}$ and activated carbon because $\mathrm{ACH}$ includes chlorine and adding it with carbon together at the same point will minimized the removal efficiency of the turbidity (Spellman, 2003). 
The optimum dosage of PAC was $0.1 \mathrm{~g} / \mathrm{L}$ for the sample with raw water turbidity 419 NTU. The impact of adding 0.1 $\mathrm{g} / \mathrm{L}$ of PAC to the coagulant decreased the turbidity from 6.84 to 4.86 NTU as shown in Figure 9. This means that the efficiency of coagulant increased by $28.95 \%$ by adding 0.1 $\mathrm{g} / \mathrm{L}$ of PAC.

The optimum dosage of PAC was $0.25 \mathrm{~g} / \mathrm{L}$ for the sample with raw water turbidity 1000 NTU. As a result of PAC addition with the coagulant decreased the turbidity from 7 to 5.2 NTU as shown in Figure 10. This means that the efficiency of coagulant enhanced by $25.71 \%$ by adding 0.25 $\mathrm{g} / \mathrm{L}$ of PAC.

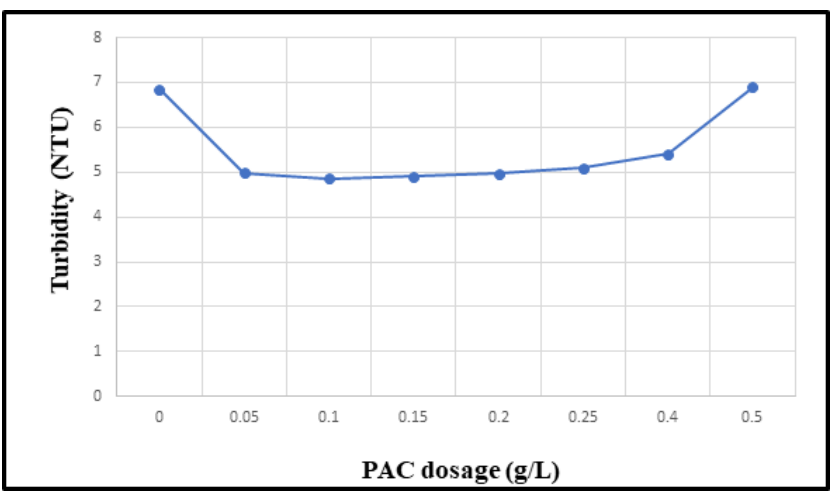

Figure 9. Optimum PAC dosage for the sample of 419 NTU

Kristiana et al. (2011) investigated the impact of the addition $0.15 \mathrm{~g} / \mathrm{L}$ of PAC to an enhanced coagulation treatment process at an existing water treatment plant on the efficiency of natural organic matter removal. As a result of the PAC addition, the removal improved by $70 \%$.

Ali (2017) added $0.1 \mathrm{~g} / \mathrm{L}$ of PAC to synthetic wastewater, the removal efficiency of turbidity increased by $96.5 \%$.

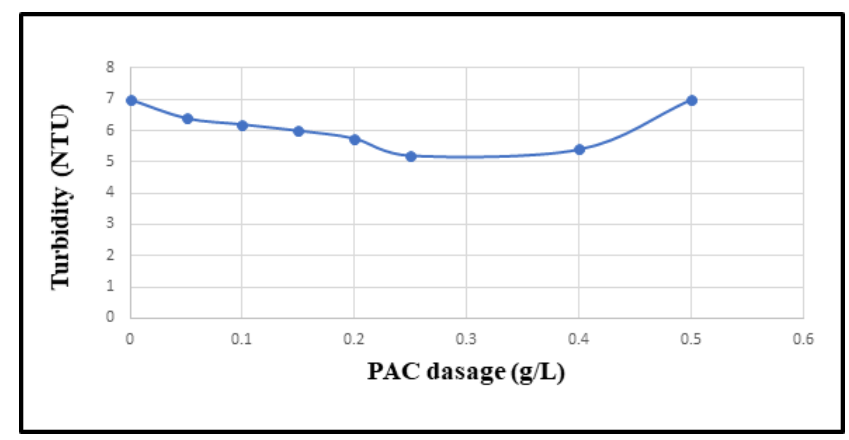

Figure 10. Optimum PAC dosage for the sample of 1000 NTU.

\subsection{Economic study}

During the evaluation of the coagulants, considerations were made concerning potential costs associated with each particular coagulant. Table 9 illustrates the summary finding of optimum dosage and the daily cost for each coagulant in different raw water turbidities. Figure 11 shows the relationships between coagulant costs at varying turbidities relative to each other. Alum was shown to have a higher cost in $\$ / d$ relative to $A C H$ within the same efficiency. The details of the calculations of the first test with raw water turbidity of 247 NTU in Table 9 are shown below:
Average input flow to the WTP is $2000 \mathrm{~m}^{3} / \mathrm{h}$ for all cases which means that the total quantity of income flow equal to $48000 \mathrm{~m}^{3} /$ day so that it can represent the real quantities as in Ifraz-2 WTP, Cost of alum/ACH per day

$$
\begin{aligned}
& \text { Weight of alum=30 mg/Lx2000 } \mathrm{m}^{3} / \mathrm{h} \times 1000 \\
& \mathrm{~L} / \mathrm{m}^{3} /(1000000 \mathrm{mg} / \mathrm{kg})=60 \mathrm{~kg} / \mathrm{h}
\end{aligned}
$$$$
\text { Volume of } \mathrm{ACH}=4 \quad \mu \mathrm{l} / \mathrm{Lx} 2000 \quad \mathrm{~m}^{3} / \mathrm{h} \times 1000
$$$$
\mathrm{L} / \mathrm{m}^{3} /(1000000 \mu \mathrm{l} / \mathrm{L})=8 \mathrm{~L} / \mathrm{h}
$$

Density of $\mathrm{ACH}=1.32 \mathrm{~kg} / \mathrm{L}$,

$$
\begin{aligned}
& \text { Weight of } \mathrm{ACH}(\mathrm{kg} / \mathrm{h})=8 \mathrm{~L} / \mathrm{h} \times 1.32 \mathrm{~kg} / \mathrm{L}=10.56 \\
& \mathrm{~kg} / \mathrm{h}
\end{aligned}
$$

Price of alum $=340 \$ /$ ton

Cost of alum in $(\$ / d)=60 \mathrm{~kg} / \mathrm{h} \times 24 \mathrm{~h} / \mathrm{d} \times 340$

$\$ /$ ton $/(1000 \mathrm{~kg} /$ ton $)=489.6 \$ / \mathrm{d}$.

Cost of $\mathrm{ACH}=1200 \$ / \mathrm{m} 3$, it is available in Turkey

Price of $\mathrm{ACH}$ in $(\$ / \mathrm{d})=8 \mathrm{~L} / \mathrm{h} \times 24 \mathrm{~h} / \mathrm{d} \times 1200$

$\$ / \mathrm{m}^{3 /}\left(1000 \mathrm{~L} / \mathrm{m}^{3}\right)=230.4 \$ / \mathrm{d}$.

This reveals that the cost ratio for one day of $\mathrm{ACH}$ to alum $=230.4 / 489.6=0.47 \%$, this means that by using $\mathrm{ACH}$ instead of alum in coagulation-flocculation process decrease the total cost to near the half for the first case of raw water turbidity of 247 NTU.

The average cost of $\mathrm{ACH}$ to alum for all cases is $68 \%$, which means the reduction of total costs by using $\mathrm{ACH}$ instead of alum is about $32 \%$.

Commonly, it can be concluded that using $\mathrm{ACH}$ instead of alum is cheaper and more efficient.

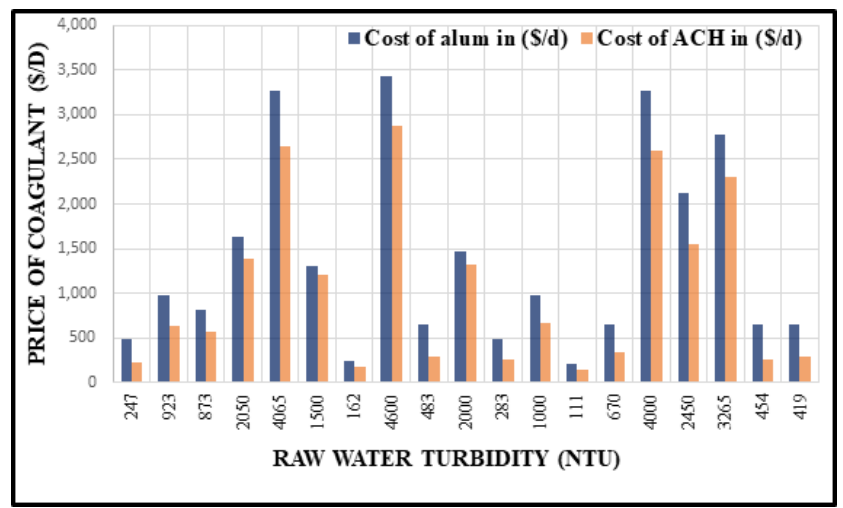

Figure 11. Coagulant costs with different raw water turbidity

\section{Conclusions}

The results revealed that the Greater-Zab River is safe for construction, and irrigation, but need treatment for drinking. The optimal settling time for the sedimentation process was 30 minutes and 40 minutes for raw water turbidity of 1000 and 2000 NTU, respectively. The optimum coagulant dosages were obtained and presented from alum and $\mathrm{ACH}$ for different raw water turbidities, and the optimum dosage of PAC as coagulant aid of 0.1 and 0.25 $\mathrm{g} / \mathrm{L}$ for raw water samples of 419 and 1000 NTU was 
determined in the experiments and reported, which increased the removal efficiency of the turbidity removal with $28.95 \%$ and $25.71 \%$ compared with absent of PAC. Moreover, the economic analysis for alum and $\mathrm{ACH}$ exposed that using $\mathrm{ACH}$ instead of alum led to reduction of cost by $32 \%$. Generally, it can be concluded that using $\mathrm{ACH}$ instead of alum is better because it is cheaper and more efficient. The expected equations for the optimum dosages (Y) for alum $(\mathrm{mg} / \mathrm{L})$ and $\mathrm{ACH}(\mu \mathrm{l} / \mathrm{L})$ dosages $(\mathrm{X})$ were $\mathrm{Y}=$ $0.04 x+14.42$, and $Y=0.01 x+0.72$, respectively.

Table 9. Cost of Ach and Alum per day

\begin{tabular}{|c|c|c|c|c|c|c|c|c|c|c|c|c|}
\hline No. & Date of Test & $p H$ & $\begin{array}{c}\text { Temprature } \\
C^{\circ}\end{array}$ & $\begin{array}{l}\text { Turbidity of } \\
\text { Raw water } \\
\text { (NTU) }\end{array}$ & $\begin{array}{l}\text { Flow } \\
\left(m^{3} / t\right)\end{array}$ & $\begin{array}{c}\text { Optimum dosage } \\
\text { of alum from Jar } \\
\text { Test }(\mathrm{mg} / \mathrm{L})\end{array}$ & $\begin{array}{c}\text { Optimum } \\
\text { dosage of } \\
\text { ACH from } \\
\text { Jar Test } \\
(\mu L / L)\end{array}$ & $\begin{array}{c}\text { Weiglt of } \\
\text { alum }(\mathrm{kg} / \mathrm{l})\end{array}$ & $\begin{array}{l}\text { Volume of } \\
\text { ACH }(\mathrm{L} / \mathrm{l})\end{array}$ & $\begin{array}{c}\text { Weight of } \\
\text { ACH (kg/h) }\end{array}$ & $\begin{array}{c}\text { Cost of } \\
\text { alum in } \\
(\$ / d)\end{array}$ & $\begin{array}{c}\text { Cost of } \\
\text { ACH in } \\
(S / d)\end{array}$ \\
\hline 1 & $02 / 01 / 2019$ & 7.49 & 11.7 & 247 & 2000 & 30 & 4 & 60 & 8 & 10.56 & 489.6 & 230.4 \\
\hline 2 & $20 / 1 / 2019$ & 7.00 & 13.8 & 923 & 2000 & 60 & 11 & 120 & 22 & 29.04 & 979.2 & 633.6 \\
\hline 3 & $21 / 01 / 2019$ & 7.11 & 13.6 & 873 & 2000 & 50 & 10 & 100 & 20 & 26.40 & 816 & 576 \\
\hline 4 & $23 / 1 / 2019$ & 7.16 & 14.2 & 2050 & 2000 & 100 & 24 & 200 & 48 & 63.36 & 1632 & 1382.4 \\
\hline 5 & $27 / 1 / 2019$ & 7.21 & 12.1 & 4065 & 2000 & 200 & 46 & 400 & 92 & 121.44 & 3264 & 2649.6 \\
\hline 6 & $30 / 1 / 2019$ & 7.08 & 14.3 & 1500 & 2000 & 80 & 21 & 160 & 42 & 55.44 & 1305.6 & 1209.6 \\
\hline 7 & 05/02/2019 & 6.94 & 13.1 & 162 & 2000 & 15 & 3 & 30 & 6 & 7.92 & 244.8 & 172.8 \\
\hline 8 & $06 / 02 / 2019$ & 7.00 & 12.6 & 4600 & 2000 & 210 & 50 & 420 & 100 & 132.00 & 3427.2 & 2880 \\
\hline 9 & $27 / 02 / 2019$ & 7.22 & 11.7 & 483 & 2000 & 40 & 5 & 80 & 10 & 13.20 & 652.8 & 288 \\
\hline 10 & $04 / 03 / 2019$ & 7.24 & 13.6 & 2000 & 2000 & 90 & 23 & 180 & 46 & 60.72 & 1468.8 & 1324.8 \\
\hline 11 & $17 / 3 / 2019$ & 7.61 & 12.8 & 283 & 2000 & 30 & 4.5 & 60 & 9 & 11.88 & 489.6 & 259.2 \\
\hline 12 & $18 / 3 / 2019$ & 7.33 & 12.2 & 1000 & 2000 & 60 & 11.5 & 120 & 23 & 30.36 & 979.2 & 662.4 \\
\hline 13 & $25 / 3 / 2019$ & 7.43 & 15.4 & 111 & 2000 & 12.5 & 2.5 & 25 & 5 & 6.60 & 204 & 144 \\
\hline 14 & 04/04/2019 & 7.71 & 18.7 & 670 & 2000 & 40 & 6 & 80 & 12 & 15.84 & 652.8 & 345.6 \\
\hline 15 & 08/04/2019 & 7.31 & 18.7 & 4000 & 2000 & 200 & 45 & 400 & 90 & 118.80 & 3264 & 2592 \\
\hline 16 & 09/04/2019 & 7.31 & 19.5 & 2450 & 2000 & 130 & 27 & 260 & 54 & 71.28 & 2121.6 & 1555.2 \\
\hline 17 & $12 / 04 / 2019$ & 7.45 & 20.2 & 3265 & 2000 & 170 & 40 & 340 & 80 & 105.60 & 2774.4 & 2304 \\
\hline 18 & $13 / 4 / 2019$ & 7.10 & 21.8 & 454 & 2000 & 40 & 4.5 & 80 & 9 & 11.88 & 652.8 & 259.2 \\
\hline 19 & $17 / 04 / 2019$ & 7.00 & 22 & 419 & 2000 & 40 & 5 & 80 & 10 & 13.20 & 652.8 & 288 \\
\hline
\end{tabular}

\section{References}

Abbas N., Wasimi S.A., and Al-Ansari N. (2016). Climate change impacts on water resources of Greater Zab River, Iraq. Journal of Civil Engineering and Architecture, 10, 1384-1402.

Abbas W.A.A. (1986). Evaluation of Tigris river water quality for different uses, M. Sc. Thesis. Univ. of Baghdad.

Al-Ansari N., Ali A., and Knutsson S. (2014). Present conditions and future challenges of water resources problems in Iraq, Journal of Water Resource and Protection, 6, 1066-1098.

Ali S.M. (2017). Treatment of Erbil municipal and dairy wastewater using Activated Carbon added to biological filtration process, M.Sc. Thesis, University of Salahaddin. Iraq.

APHA. (2005). Standard methods for the examination of water and wastewater, $21^{\text {st }}$ ed. American Public Health Association, Washington DC, 1220p.

Ayers R.S., and Westcot D.W. (1985). Water quality for agriculture, Food and Agriculture Organization of the United Nations Rome.

Aziz S.Q. (2006). Assessment of Greater-Zab river water quality at Ifraz station for drinking and irrigation purposes, Journal of Zanco, Salahaddin University-Erbil, 18(3), 131-144.

Aziz S.Q. (2008). Monitoring variation of some water quality parameters of greater-Zab river at Ifraz station during fourteen months, Journal of Zanco, Salahaddin University-Erbil, 20(3), 115-133.

Aziz S.Q., Slewa E.O., and Abdullah W.A. (2017). Evaluation of water quality for Lesser-Zab River for various applications, Kirkuk University Journal for Scientific Studies, 12, 209-231.
Brandt M.J., Johnson K.M., Elphinston A.J., and Ratnayaka D.D. (2017). Twort's Water Supply, Seventh Edition, Amsterdam: Butterworth-Heinemann.

Crittenden J.C., Trussell R.R., Hand D.W., Howe K.J., and Tchobanoglous G. (2012). MWH's water treatment: principles and design. Third Edition, Canada. John Wiley \& Sons, Inc.

Erbil Water Directorate (EWD) (2019). General Directorate of Water and swergare, Ministry of Municipality and Tourism, Erbil, Kurdistan Region, Iraq.

Hanna N.S., and Shekha Y.A. (2015). Using aquatic insects in water quality assessment of some branches of Greater Zab River within Erbil City, Iraqi Kurdistan Region, American International Journal of Research in Formal, Applied \& Natural Sciences, 18-22.

Iraqi Drinking Water Quality Standards (1986). Environmental Engineering-Water Analysis, University of Mosul (1990).

Issa H.M. (2017). Evaluation of water quality and performance for a water Treatment Plant: Khanaqin City as a case study, Journal of Garmian University, 802-821.

Kafia M.S., Slaiman G.M., and Nazanin M.S. (2009). Physical and chemical status of drinking water from water treatment plants on Greater Zab River, Journal of Applied Sciences and Environmental Management, 13(3), 89-92.

Khan A.A., and Ahmad S.K. (2018). Performance evaluation of water treatment plant at Nangloi, New Delhi: A Case Study, International Journal of Research in Engineering and Technology, 7(8), 49-60. 
Kristiana I., Joll C., and Heitz A. (2011). Powdered activated carbon coupled with enhanced coagulation for natural organic matter removal and disinfection by-product control: Application in a Western Australian water treatment plant, Chemosphere, 83(5), 661-667.

Kucche K., Jamkar S., and Sadgir P. (2015). Quality of water for making concrete: A review of literature, International Journal of Scientific and Research Publications, 5(1), 1-10.

Metcalf and Eddy (2014). Wastewater Engineering: Treatment and Reuse, $5^{\text {th }}$ edition, Inc., New York. Mc Graw-Hill.

Puri P., Yenkie M., Rana D., and Meshram S. (2015). Application of water quality index (WQI) for the assessment of Durface water quality (Ambazari Lake), European Journal of Experimental Biology, 5, 37-52.

Shareef K.M., and Muhamad S.G. (2008). Natural and drinking water quality in Erbil, Kurdistan, Current World Environment, 3(2), 227-238.

Shekha Y.A. (2016). Evaluation of water quality for Greater Zab River by principal component analysis/Factor analysis, Iraqi Journal of Science, 57(4B), 2650-2663.

Singh S., and Hussian A. (2016), Water quality index development for groundwater quality assessment of Greater Noida subbasin, Uttar Pradesh, India, Cogent Engineering, 2016(3), 1177155.

Spellman F.R. (2003). Handbook of Water and Wastewater Treatment Plant Operations, New York "CRC press" Lewis publishers.

Toma J.J. (2013). Evaluating raw and treated water quality of Greater Zab River within Erbil City by index analysis, International Journal of Emerging Technologies in Computationaland Applied Sciences (IJETCAS), 3(2), 147-154.

Vieira P., Alegre H., Rosa M., and Lucas H. (2008). Drinking water treatment plant assessment through performance indicators, Water Science \& Technology: Water Supply, 8(3), 245-253.

WHO (2011). Guidelines for drinking-water quality, WHO chronicle, 38, 104-108.

WHO (2017). Guidelines for drinking-water quality: first addendum to the fourth edition, www.world.taobao.com, Powdered Activated Carbon Speciifaction. 